\title{
Nutri garden: A Low Cost Sustainable Approach to Improve Nutritional Security of Farm Families
}

\author{
Prema B. Patil", S. A. Biradar, Sangeeta Jadhav and B. C. Kohlar \\ Krishi Vigyan Kendra, Hitnalli farm, Vijayapura, University of Agricultural Sciences, \\ Dharwad, Karnataka, India \\ *Corresponding author
}

\section{A B S T R A C T}

\section{Keywords \\ Nutrigarden farm, Families, Low, Cost, Sustainable, Agriculture \\ Article Info \\ Accepted: \\ 24 October 2020 Available Online: \\ 10 November 2020}

The main purpose of a nutri garden is to provide the family with fresh vegetables and fruits rich in nutrients and energy on a daily basis. It is a low cost sustainable approach for reducing malnutrition and increasing food, nutrition and economic security. The study was carried out with the objective of promoting dietary diversification to improve the nutritional security of the farm families. It was implemented in Tajpur and Hadagali village of Vijaypur taluk, Karnataka. The sample size comprised of 36 farm women. Data was collected through 24 hour recall method. General information was collected using questionnaire. Percentage adequacy was analysed using NIN standards. The results revealed an improvement in consumption of different food groups ranging from 4 to 34 percent. Further the percentage adequacy regarding average consumption of nutrients before and after the implementation of nutrigarden revealed an improvement in consumption of different nutrients ranging from 1 to 5 percent. Thus, it can be concluded that nutrigarden has not only improved the consumption percentage of diversified fruits and vegetables but also has improved the nutrient consumption status of the farm families.

\section{Introduction}

The quality of life has suffered due to various economic, social and cultural causes and also lack of dietary diversification for example micronutrient deficiency is common and causes impaired physical and cognitive development. It is required to have access to a perennial supply of vegetables and nutrition. The main purpose of a nutri garden is to provide the family with fresh vegetables rich in nutrients and energy on a daily basis. A well laid out nutri garden helps to meet the entire requirements of fruits and vegetables for a family for the entire year. It is a low cost sustainable approach for reducing malnutrition, increasing awareness of vegetable production and achieving food, nutrition and economic security.

The main objectives of this study include to promote dietary diversification to improve the nutritional status of the farm families; To make available vegetables and fruits throughout the year; To promote family farming. 


\section{Materials and Methods}

The nutrigarden was implemented in Tajpur and Hadagali village of Vijaypur taluk. The sample size comprised of 36 farm women. Seeds of 21 types of vegetables including solaneceous vegetables, other vegetables, roots, tubers and seedlings of different fruits and medicinal plants were given to the farm women. Trainings were conducted on importance of nutri garden and its nutritional, economical and psychological benefits. Nutri garden was implemented in an area of $100 \mathrm{Sq}$ $\mathrm{mts}$ for each family. Data was collected using questionnaire and 24 hour recall method. Percentage adequacy of nutrients was analysed using NIN standards.

\section{Results and Discussion}

Demographic variables revealed that majority $(53 \%)$ of the respondents belonged to the age group of 31-40 years followed by 44 percent from the age group of 20-30 years. Only three percent of them belonged to 41-40 years age group. With regard to caste, 81 percent of them belonged to other category and 19 percent belonged to SC category. Ninety two percent of the farmwomen were home makers followed by business (5\%) and 3 percent were in service. Fifty five percent of the respondents belonged to joint family, 28 percent of them belonged to nuclear family and 17 percent of the sample belonged to extended family. Further 72 percent of the respondents had completed primary education, 22 percent had completed secondary education and six percent of them were illiterate. With regard to experience in farming, 72 percent of the farmwomen had less than five years of experience in farming and 25 percent of them had more than five years of experience in farming and only three percent of them had no experience in farming. The main purpose of nutrigarden for hundred percent of the respondents was financial benefits. They were not aware or bothered about the nutritional benefits. More than half (56\%) of the farmwomen were spending two hours on an average per day in nutrigarden and 44 percent were spending one hour in the nutrigarden (Table 1).

The percentage adequacy regarding average consumption of food before and after the implementation of nutrigarden revealed an improvement in consumption of all the food groups ranging from 4 to 34 percent. However, the consumption of roots and tubers did not reach the NIN standards. Similarly with regard to fruit consumption, an improvement of only two percent over NIN standards was observed. Further there was a decrease in consumption of sugar by 8 percent as awareness was created through trainings on the bad effects of sugar consumption on their health (Table-2). The study by Pradhan et.al on nutrition garden utilization data of 2015-16 and 2016-17 following two years of intervention and compares it with the baseline. A representative sample size of 190 households was selected at each study site and their change in food consumption (quantity and frequency) was compared between baseline (2014) and endline (2017). Over the period (2015-17), 43 and 28 varieties of plants were found in the nutrition gardens of Koraput and Wardha, respectively as against two or three types of plants generally grown during the baseline (2013-14). The entire produce from nutrition garden was used for household consumption in Wardha while in Koraput, 10-20 per cent was also distributed to neighbours or sold. Monthly per capita consumption of fruits and vegetables, both quantity consumed and frequency of consumption, showed marked increase between baseline and endline. Increased availability of different groups of vegetables also fulfilled the household nutritional requirements. 
Table.1 Demographic variables of the respondents

\begin{tabular}{|c|c|c|c|c|}
\hline Sl.no. & Particulars & Classification & Number & Percent \\
\hline \multirow[t]{3}{*}{1.} & Age & $20-30 \mathrm{yrs}$ & 16 & 44 \\
\hline & & $31-40 \mathrm{yrs}$ & 19 & 53 \\
\hline & & $41-50 \mathrm{yrs}$ & 1 & 3 \\
\hline \multirow[t]{3}{*}{2.} & Caste & $\mathrm{SC}$ & 7 & 19 \\
\hline & & ST & - & 0 \\
\hline & & Others & 29 & 81 \\
\hline \multirow[t]{3}{*}{3.} & Occupation & Home maker & 33 & 92 \\
\hline & & Business & 2 & 5 \\
\hline & & Service & 1 & 3 \\
\hline \multirow[t]{3}{*}{4.} & Family size & Nuclear & 10 & 28 \\
\hline & & Joint & 20 & 55 \\
\hline & & Extended & 6 & 17 \\
\hline \multirow[t]{4}{*}{5.} & Education & Primary school & 26 & 72 \\
\hline & & Secondary school & 8 & 22 \\
\hline & & Degree & - & 0 \\
\hline & & Illiterate & 2 & 6 \\
\hline \multirow[t]{3}{*}{6.} & Experience in farming & $<5$ years & 26 & 72 \\
\hline & & $>5$ years & 9 & 25 \\
\hline & & No experience & 1 & 3 \\
\hline \multirow[t]{3}{*}{7.} & Purpose of nutrigarden & Social or recreational & 0 & \\
\hline & & Family health & 0 & \\
\hline & & Financial benefit & 36 & 100 \\
\hline \multirow[t]{2}{*}{8.} & $\begin{array}{l}\text { Average man hours spent } \\
\text { in nutrigarden }\end{array}$ & 1 & 16 & 44 \\
\hline & & 2 & 20 & 56 \\
\hline
\end{tabular}

Table.2 Average consumption of food and percentage adequacy before and after implementation of nutrigarden

\begin{tabular}{|l|c|c|c|c|c|}
\hline Food group & $\begin{array}{c}\text { Standard } \\
\text { Value }\end{array}$ & \multicolumn{2}{|l|}{ Average food consumption } & \multicolumn{2}{l|}{ Percentage adequacy } \\
\hline & & Before & After & Before & After \\
\hline Pulses & $75(\mathrm{~g})$ & 79.2 & 82.7 & 105.6 & 110.26 \\
\hline $\begin{array}{l}\text { Milk and milk } \\
\text { products }\end{array}$ & $300(\mathrm{ml})$ & 189.5 & 201.5 & 63.16 & 67.16 \\
\hline Roots and tubers & $200(\mathrm{~g})$ & 152.6 & 187.5 & 76.3 & 93.75 \\
\hline GLV & $100(\mathrm{~g})$ & 88.9 & 122.3 & 88.9 & 122.3 \\
\hline Other vegetables & $200(\mathrm{~g})$ & 193.2 & 220.8 & 96.6 & 110.4 \\
\hline Fruits & $100(\mathrm{~g})$ & 92.6 & 102.2 & 92.6 & 102.2 \\
\hline Sugar & $30(\mathrm{~g})$ & 42.8 & 40.3 & 142.66 & 134.33 \\
\hline Fat & $25(\mathrm{~g})$ & 21.7 & 23.5 & 86.8 & 94.0 \\
\hline
\end{tabular}


Table.3 Average consumption of nutrients and percentage adequacy before and after implementation of nutrigarden

\begin{tabular}{|l|c|c|c|c|c|}
\hline Food group & $\begin{array}{c}\text { Standard } \\
\text { Value }\end{array}$ & \multicolumn{2}{|l|}{ Average food consumption } & \multicolumn{2}{l|}{ Percentage adequacy } \\
\hline & & Before & After & Before & After \\
\hline E(kcal) & 2230 & 1869 & 1882 & 84 & 84 \\
\hline P (gm) & 55 & 44 & 46 & 80 & 96 \\
\hline Fat $(\mathbf{g m})$ & 25 & 24 & 25 & 80 & 83 \\
\hline Fibre (gm) & 30 & 24 & 25 & 81 & 86 \\
\hline Fe (mg) & 21 & 17 & 18 & 97 & 98 \\
\hline Ca (mg) & 600 & 584 & 585 & 36 & 36 \\
\hline Carotene $(\boldsymbol{\mu g g})$ & 4800 & 1707 & 1721 & 35 & 40 \\
\hline Vit C(mg) & 40 & 14 & 16 & & 86 \\
\hline
\end{tabular}

Table.4 Economics

\begin{tabular}{|c|c|c|c|}
\hline Gross cost (Rs.) & Gross return (Rs.) & Net profit (Rs.) & B:C ratio \\
\hline $\mathbf{1 6 0 0}$ & 3841 & 2241 & 2.4 \\
\hline
\end{tabular}

Further the percentage adequacy regarding average consumption of nutrients before and after the implementation of nutrigarden revealed an improvement in consumption of different nutrients ranging from 1 to 5 percent (Table 3). Suri (2020) in her report has mentioned that an unbalanced diet and lack of food is directly linked to high rates of stunting, excessive weight and death in children under five years of age. There is a need to look at multiple strategies to combat the issue of food security. Community and nutrition gardens can play an important role in enhancing national food security and dietary diversity to combat malnutrition.

With regard to economics, on an average a family is spending Rs. 1200 per month and Rs. 4800 rupees for four months (Table 4). Whereas through implementation of nutrigarden a family has saved Rs.2241 by spending Rs.1600 for four months apart from household consumption. Shubha et al., (2020) in the food and scientific reports have documented that nutri-gardens can not only help in improving the nutritional status of rural household but also generate small but constant source of income, especially for women. The article has emphasized the contribution of Nutri-garden towards achieving the sustainable development goals.

In conclusion, the home maker i.e the women of the family needs to be educated about the importance of nutrigarden as the health of the family is in the hands of the home maker. Diversification of diet in menu planning also needs to be educated to the women through nutrigarden. Nutrigarden has not only improved the consumption percentage of different food groups but also the diversification of vegetables and fruits has improved the nutrient consumption status of the family. The farm women gave the feed back that availability of nutrigarden surrounding their house improved the frequency of consumption which would not have been possible if they had to purchase it from outside. Moreover the whole family was spending one or two hours daily in the 
evening which gave them the satisfaction that they were consuming the self grown vegetables. It was also a good opportunity for them to create interest and give practical experience to their kids about farming. In today's situation of COVID-19 pandemic, nutri garden is the best choice for individual families to avoid infection by purchasing from outside, growing of immune-boosting plants and consuming it daily and finally remaining self-contended and selfsustainable.

\section{References}

Aliza Pradhan, Raju Sathanandhan, Akshaya kumar Panda and Rupal Wagh (2018), Improving household diet diversity through promotion of nutrition gardens in India, American journal of Food Science and Nutrition, 5 (2): 43-51.

Kumari Shubha, Anirban Mukherjee, Shreya Anand, Tanmay Kumar Koley and Ujjwal Kumar (2020), Nutri-garden for achieving sustainable development Goals (SDGs). Food and Scientific reports, Vol.1, Pg. 27.

Gopalan,C., Rama Sastri,B.V and Balasubramanian,S.C. (2016). Nutritive value of Indian foods. National Institute of Nutrition, Hyderabad, India, 89-117.

Suri Shobha (2020) Nutrition gardens: A sustainable model for food security and diversity. ORF Issue brief no. 369, Observer Research Foundation.

\section{How to cite this article:}

Prema B. Patil, S. A. Biradar, Sangeeta Jadhav and Kohlar, B. C. 2020. Nutri garden: A Low Cost Sustainable Approach to Improve Nutritional Security of Farm Families. Int.J.Curr.Microbiol.App.Sci. 9(11): 3662-3666. doi: https://doi.org/10.20546/ijcmas.2020.911.440 